\title{
KONSEP EKONOMI PADA MASA KHULAFAURRASYIDIN
}

\section{(Abu Bakar As-Sidiq, Umar bin Khatab, Utsman bin Affan, Ali bin Abi Thalib)}

\author{
Mirna Rafki/90100118012/Ekonomi Islam (A)
}

Khulafaurrasyidin ialah penerus kepemimpinan sesudah Rasulullah SAW wafat. Sehingga kebijakan ekonomi pada masa khulafauurasyidin ini mengikut dari kebijakankebijakan yang telah di bangun oleh Rasulullah. Adapun yang khalifah yang melanjutkan masskepemimpinan Rasulullah adalah:

\section{- Masa Abu Bakar As-Sidiq}

Sesudah wafatnya Rasulullah, Abu Bakar kemudian diangkat untuk menjadi khalifah oleh kalangan muslimin. Masa kepemimpinan Abu Bakar hanya bertahan 2 tahun. Dalam masa kepemimpinannya ia banyak memperoleh kesulitan-kesulitan antara lain yakni permasalahan dalam pengumpulan zakat, banyak orang-orang yang enggan untuk membayar zakat, sehingga Abu Bakar memutuskan untuk memerangi kaum-kaum tersebut melalui perang Riddah ataupun dikenal dengan perang melawan kemurtadan. Sesudah kekhalifannya berjalan 6 bulan ia kemudian pindah ke Madinah, bertepatan dengan pindahnya Rasulullah, dibangunlah Baitul Maal setelah itu, meneruskan pendistribusian harta sebagaimana masa Rasulullah SAW. Ia juga memperbolehkan adanya sistem penggajian, misalnya untuk khalifah digaji 2,5 ataupun 2,75 dirham, namun jumlah tersebut dianggap kurang sehingga ditetapkan 2000 atau 2500 dirham dan menurut penjelasan lain 6000 diham/tahun. Dalam masa kepemimpinannya ia sangat mengedepannya ketelitian pembayaran zakat. Prinsip pendistribusian zakat yang digunakan Abu bakar yaitu Kesamarataan, ia tidak membeda-bedakan antara kalangan yang telah terlebih dahulu memeluk ajaran agama islam dengan yang baru memeluk agama islam.

\section{- Masa Umar bin Khatab}

Umar bin Khatab ialah khalifah ke 2 sesudah Abu Bakar wafat. Masa kepemimpinan Umar berlangsung sepanjang 10 tahun. Banyak kebijakan-kebijakan yang diterapkan oleh Umar salah satunya yaitu inovasi dalam sektor pertanian seperti memberikan tanah pertanian untuk dikelola oleh masyarakat, namun jika sepanjang 3 tahun ia gagal mengelolanya maka ia akan kehilangan kepemilikan hak atas tanah tersebut. Tidak hanya itu, pada masa Umar beban pajak dikurangi hal tersebut dilakukan untuk memperlancar bahan-bahan kebutuhan yang hendak masuk ke kota-kota. Tidak hanya itu, Umar juga 
mengembangkan pembangunan Baitul Maal, bersamaan dengan ekspansi wilayah serta perang yang banyak dimenangi. Keberadaan Baitul Maal memberikan dampak yang positif karena dana zakat semakin banyak terkumpul. Dimana harta yang terdapat di Baitul Maal dianggap sebagai milik kalangan muslim sedangkan amilnya hanya sebegai pihak yang mengelola ataupun memegang amanah. (Mudhiiah, 2016). Ada 2 kategori kebijakan zakat yang diterapkan Umar, yaitu amwal bathinah (harta yang mencakup emas, perak dan sejenisnya), dan amwal zhahirah (harta yang mencakup barang dagangan, peternakan, pertanian, madu dan sejenisnya).(Aqbar, 2019).

\section{- Masa Utsman bin Affan}

Diangkatnya Utsman bin Affan selaku khalifah dianggap hal baru dalam pemerintahan islam, Usman diharapkan mampu untuk memberikan kemakmuran bagi masyarakat karena banyaknya kekacauan yang terjadi sesudah Umar bin Khatab wafat. Dalam bidang ekonomi pada masa Utsman bin Affan tumbuh dengan pesat, dimana pada pemerintahan Utsman menerapkan prinsip politik ekonomi, prinsip-prinsip tersebut yaitu dengan membangun politik ekonomi berbasis islam, tidak berbuat kejam kepada masyarakat dalam menetapkan pajak, harta kaum muslimin wajib diberikan ke Baitul Maal, Utsman pula menetapkan harta kaum kafir untuk diserahkan ke Baitul Maal dan memberikan hak mereka serta tidak berbuat kejam terhadapnya. Tidak hanya itu pegawai pajak diwajibkan untuk menjaga amanah serta patuh terhadap janjinya, dan harta benda masyarakat harus diawasi dengan baik supaya terhindar dari penyelewengan. (Rahmawati, 2015)

\section{- Masa Ali bin Abi Thalib}

Khalifah Ali bin Abi Thalib dikenal sebagai khalifah yang sangat sederhana, ia diwarisi wilayah pemerintahan yang sangat luas. Dalam mengelola perekonomian Ali sangat hati-hati. Tidak hanya itu ia dengan sukarela menarik dirinya dari daftar yang menerima bantuan dari Baitul Maal. Ali mengurus keuangan Negara dengan sangat teliti, apalagi setiap tahunnya ia memberikan dana sebesar 5000 dirham. Salah satu usahanya yang fantastis yaitu dengan menerbitkan mata uang atas nama pemerintahan islam, hal tersebut membutikan pada masa pemerintahannya telah berkembang ilmu teknologi.(Rahma, Nur. \& Idris, 2019). 


\section{DAFTAR PUSTAKA}

Aqbar, K. \& A. I. (2019). Kontekstualisasi Ekonomi Zakat Dalam Mengentaskan Kemiskinan: Studi Kebijakan Zakat Umar Bin Khatab Dan Perzakatan Di Indonesia. Laa Maysir, 6(2).

Mudhiiah, K. (2016). Analisis Sejarah Pemikiran Ekonomi Islam Masa Klasik. Iqthishada, $8(2)$.

Rahma, Nur. \& Idris, M. (2019). Masa Keemasan Keuangan Islam (Perspektif Sejarah). Jurnal Ekonomi Bisnis Syariah, 2(1).

Rahmawati, N. (2015). Sistem Pemerintahan Islam Di Bawah Kepemimpinan Khalifah Utsman Bin Affan Tahun 644-656. 